\title{
The Malvinas (Falkland) Plateau derived from Africa? Constraints for its tectonic evolution
}

\author{
Victor A. Ramos ${ }^{1 *}$, Farid Chemale², Juan P. Lovecchio³, and Maximiliano Naipauer ${ }^{4}$ \\ ${ }^{1}$ Instituto de Estudios Andinos don Pablo Groeber (IDEAN), Universidad de Buenos Aires-Conicet, Argentina \\ ${ }^{2}$ Programa de Pós-Graduação em Geologia, Universidade do Vale do Rio dos Sinos, Brazil \\ ${ }^{3}$ YPF S.A., Exploration, Buenos Aires, Argentina \\ ${ }^{4}$ Instituto de Geocronología y Geología Isotópica (INGEIS), Universidad de Buenos Aires-Conicet, Argentina \\ *Corresponding author. Email: victoralbertoramos@gmail.com.
}

\begin{abstract}
The latest studies on the tectonic evolution of the Malvinas (Falkland) Islands and their adjacent continental plateau further east are analyzed to assess a long controversy regarding the origin of these islands. Although new technologies and exploratory drillings have brought new data in recent times, the debate on the geological evolution of this area remains open. The two dominant hypotheses are analyzed by assessing the eventual collision

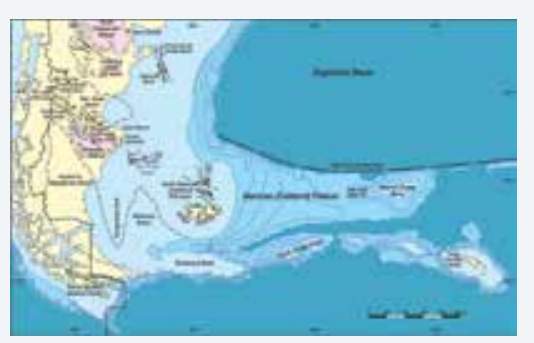
between the islands and the South American continent, the presence of a large transcontinental fault such as Gastre, the potential $180^{\circ}$ rotation of the Malvinas Islands, and the occurrence of a megadecollement with opposite vergence. These hypotheses are contrasted with the processes that have occurred in Patagonia, especially those based on the new isotopic data on the Maurice Ewing Bank at the eastern end of the Malvinas Plateau, and the current knowledge of the adjacent Malvinas Basin. The new data highlights the inconsistencies of certain models that propose that these islands migrated from the eastern African coasts near Natal, to their current position and rotated $180^{\circ}$ around a vertical axis. The new observations support the hypothesis that postulates that the islands have been part of the South American continent since before the Paleozoic.
\end{abstract}

\section{Keywords:}

Malvinas (Falkland) Plateau, rotation, paleomagnetic data, collision, microcontinent

\section{Introduction}

The tectonic evolution of the South Atlantic Ocean is heavily constrained by the adjustment and mismatch of several continental blocks associated with the fitting of South America and Africa as part of the supercontinent of Pangea. Several alternatives were presented based on different criteria in recent years, where the Malvinas (Falkland) Islands and their adjacent continental blocks play a significant role in the reconstructions. The finding of important hydrocarbon resources outboard the Outeniqua basin offshore South Africa, which is modifying the scenario of hydrocarbon resources in this country, further increases the need for a proper reconstruction and precise paleogeography of the South Atlantic Ocean to evaluate the South American conjugate continental margin. 


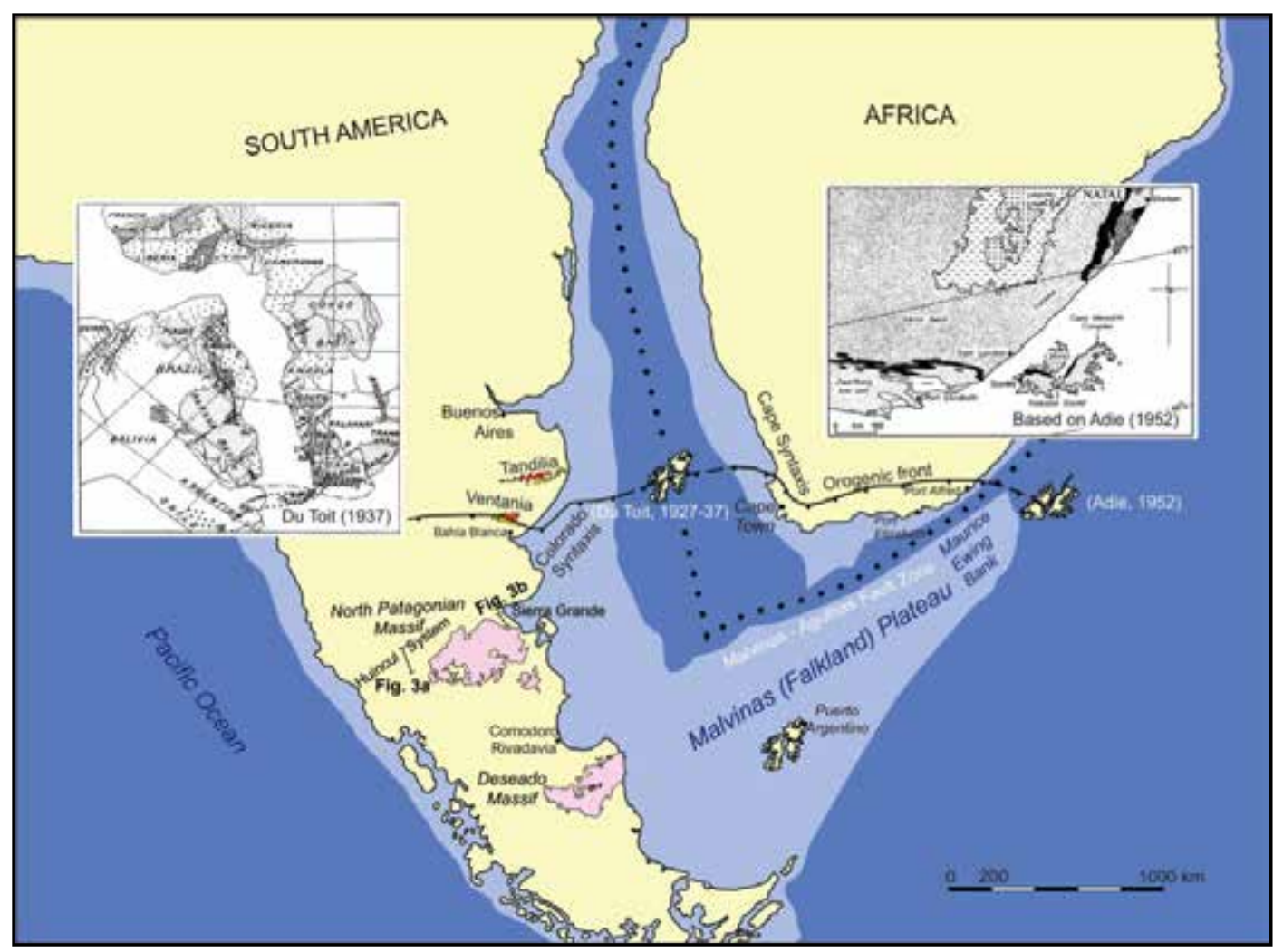

Figure 1. Two contrasting alternatives for the origin of the Malvinas (Falkland) Plateau (based on Ramos and others[1]). Note locations of figures $3 a$ and $3 b$.

The aim of the present review is to assess the contrasting tectonic evolution proposed in the last two or three years based on old and new data obtained in the Malvinas (Falkland) Plateau. Most of the recent works can be divided into two different groups. One of these is based on a stable relationship between the South American continent and the different elements of the plateau since at least the Neoproterozoic. This option contrasts with the African-derived alternative that divides the plateau into two different blocks, which would have collided with South America in Jurassic-Cretaceous times.

\section{Previous works}

One of the first reconstructions of the paleogeography of the South Atlantic Ocean was advanced by Du Toit [2,3], who proposed a location of the Malvinas Islands between South America and Africa (Fig. 1). This South African geologist located the Malvinas Islands in the offshore continental platform between the Ventania System of Buenos Aires, and the Cape System of South Africa based on the geological correlation found by professor Keidel [4,5,6,]. This reconstruction took in consideration the stratigraphy of both systems and the shared late Paleozoic glacial deposits, and highlighted the coincidence in age and discontinuities of the common sedimentary sequences. Some years later, another South African geologist, Adie[7], who had worked in the Malvinas Islands, based on the southern vergence of the structures, located the islands "upside down", but in the eastern opposite side of South Africa (see Figure 1). This way, both the islands and the Cape System, which shares a common stratigraphy, present the same northern vergence.

This proposal was analyzed by Suero[8] and Borrello[9] who, based on the continuity of the late Paleozoic sedimentary basins of Patagonia, preferred the Present normal position of the islands attached to South America. The latter author disregarded Adie's proposal based on the common stratigraphic and paleontological characteristics between the Malvinas Islands and Patagonia.

Adie's hypothesis was almost forgotten for many years until the paleomagnetic work of Mitchell and others[10]. These authors published a high impact article in Nature, which deserved the journal cover, based on the paleolatitudes obtained from Mesozoic dolerite dyke swarms together with a $120^{\circ}$ rotation in the paleopoles, that resurrected the "upside down" hypothesis. This was partially confirmed by some other paleomagnetic studies performed by Taylor and Shaw[11]. After these geophysical works, most of the British authors started to support that the Malvinas Islands were located in the offshore of South Africa, in front of the Natal province, in the late Paleozoic, and that after a subsequent rotation during 
Jurassic times, prior to the opening of the South Atlantic, the islands departed from Africa to be transferred to South America (see Stone[12,13], and references therein).

Even though many authors have backed the hypothesis that the islands were in South Africa and later, in Jurassic times, were transferred to South America, this hypothesis has a series of drawbacks that require further evidence to be sustained. In order to evaluate the African-derived alternative for the islands, several premises required for this hypothesis should be analyzed.

\section{1.- MALVINAS ISLANDS DERIVED FROM AFRICA}

\section{Collision of Malvinas Islands microplate with South America}

As pointed out by Martin[14] in his editorial comments early on in Nature, 1986, the new paleomagnetic data, even though partially consistent with the "upside down" location in front of Natal, present new and more difficult problems. The main problems were for this author how this block rotated and moved from that position to its present setting. Several alternatives were suggested to explain this displacement.

Based on paleomagnetic data, Ben Avraham and others[15] proposed the existence of an independent block, the Lafonia microplate. This small block would have two advantages - first, it would facilitate a $120^{\circ}$ rotation, and after this, it would make it easier to transport the islands to South America. However, there is no evidence of any suture between South America and the Malvinas Islands as recognized by Richards and others[16]. These authors, based on the study of the offshore seismic lines in the platform between the islands and the continent, disregarded the presence of a crustal suture.

The existence of an independent microplate to make the drift and collision to South America possible would also have the problem that it would require a subduction zone on its leading edge, which would have produced a volcanic arc and, after the collision, a suture. There is no evidence of either of these two things. This fact was soon realized by several authors, such as Ben Avraham et al.[15] who, in order to solve the lack of a suture, proposed that Patagonia was a terrane independent from South America that moved together with the Lafonia microplate after its rotation in Jurassic times.

Another drawback for the collision of the Lafonia microplate against South America is the rift preserved in the Malvinas Basin (see location in Fig. 5). New studies performed in this basin show two stages of rifting, one in the Late Triassic and another in Early-Middle Jurassic times (see Lovecchio and others[17]). Seismic sections across the rift (Fig. 6) show no deformation as expected if there had been a collision against a microplate (see discussion below).

\section{The Gastre continental fault system}

The proposal of Patagonia attached to the Malvinas Plateau, both together as an independent terrane, explains the lack of a suture and the nonexistence of a volcanic arc on the Lafonia microplate, but a continental scale fault system and a transform fault in the offshore would be required to displace this huge terrane from Africa to its present position.

The northern boundary of the Patagonia terrane as proposed by Ben Avraham et al.[15] was a large right-lateral transpressional shear zone, which bounded the North Patagonian massif to the north from the rest of Gondwana. However, this northern limit coincides with the proposed suture between Patagonia and Gondwana, which was formed by orthogonal contraction with almost no evidence of strike-slip motion[18,19] during the late Paleozoic. The development of the Ventania and Cape fold and thrust belts, as well as the Colorado, Garies, and Cape syntaxes[19,20], preclude the existence of such transform fault north of Patagonia in Jurassic times[1].

To avoid this problem, Marshall[21] proposed that the boundary was determined by the Gastre intracontinental fault system, suggested by Rapela and Pankhurst[22], which is located south of the North Patagonian Massif. However, that hypothesis requires a displacement larger than $500 \mathrm{~km}$ along that fault system produced between $190 \mathrm{Ma}$, age of emplacement of the older dyke swarms in the Malvinas Islands, and $170 \mathrm{Ma}$, a cooling episode of uplift based on fission track ages of these dikes[23]. This would require a displacement rate of more than $42 \mathrm{~mm}$ per year along such transcontinental fault. Several recent studies on the Gastre fault system, in the classic locality where it was defined by Coira and others[24], have proved that this fault is a ductile shear zone of Paleozoic age, with no evidence of Jurassic or younger offsets of that magnitude[25,26,27], among others. 
If no displacement, such as required, ever occurred along the Gastre fault system, Patagonia and the Malvinas Islands could not have moved together as a single continental block as proposed by several authors[16,28,29,30,31], among many others.

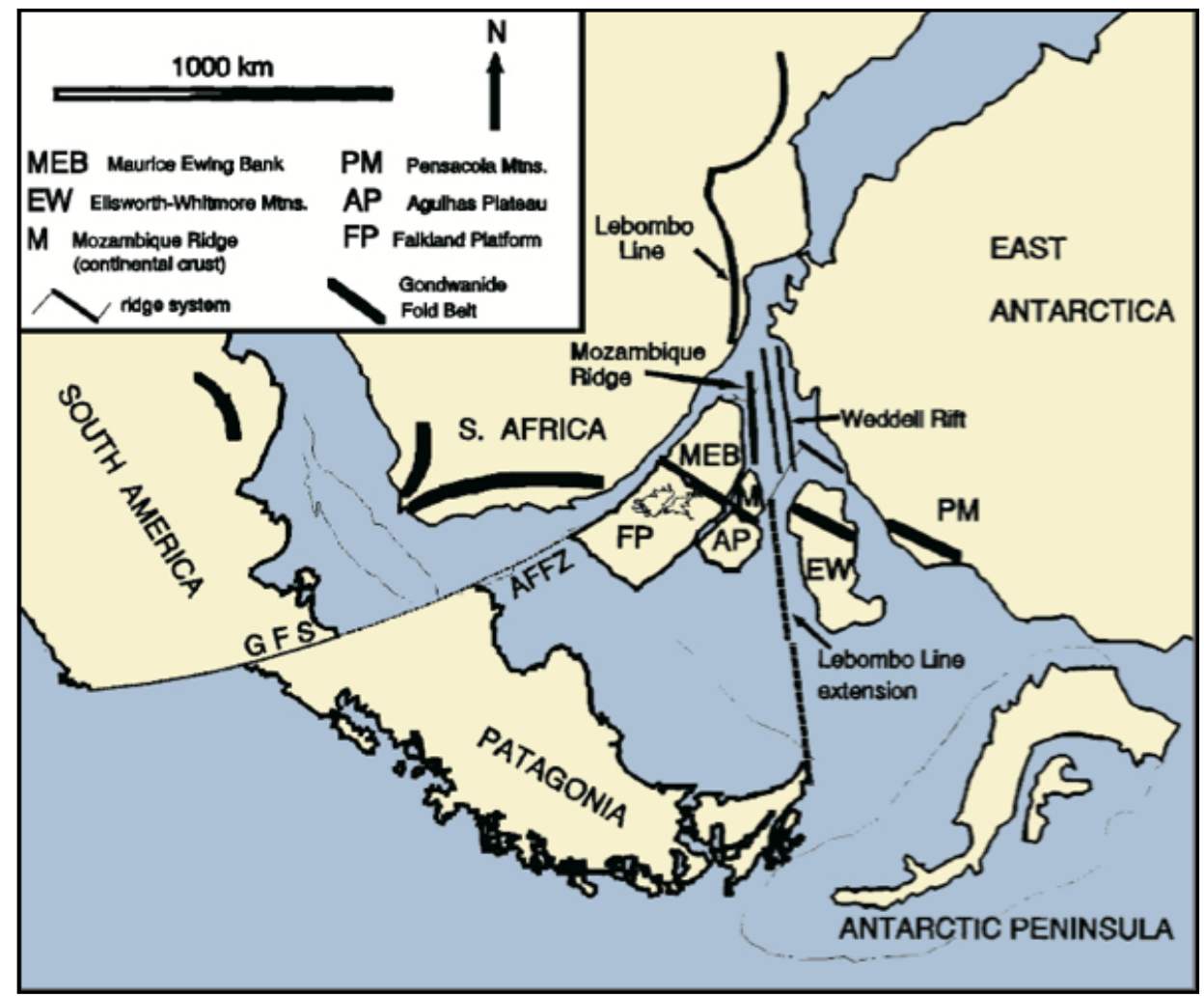

Figure 2. Proposed paleogeography based on the Gastre Fault System (G.P.S.) to accommodate the Malvinas Islands close to the Natal offshore (after Marshall[21]). See text for discussion.

\section{The Jurassic rotation of the Malvinas Islands}

Several alternatives have been proposed for a clock-wise rotation of the islands of at least $120^{\circ}$. The most feasible way this is possible would involve a rotation of the microplate associated to oceanic crust formation, as could be observed in the opening of the Bay of Biscay, between Spain and England[32]. One of the most popular alternatives for this model is the "double-saloon-door" rifting and seafloor spreading as proposed by Martin[29] and supported by Dalziel and others[30]. The main drawback is that there is no evidence of oceanic crust older than the early Cretaceous during the South Atlantic opening, where all the magnetic anomalies are parallel to the Agulhas-Malvinas transform without any evidence of rotation[33,34]. From the onshore perspective, as pointed out by Stone[13], the case for rotation of a microplate appears overwhelming, but offshore data do not support rotation and are compatible with a high degree of extension of a fixed Malvinas Plateau attached to South America[35,1].

Some other authors proposed a $120^{\circ}-150^{\circ}$ rotation during the break-up of Gondwana, previous to seafloor spreading without participation of oceanic crust but, as noticed by Stone ${ }^{13}$, timing is crucial and most of the rotation of the microplate must have been pre-Cretaceous and probably mid-Jurassic. There is some consensus that rotation was a relatively rapid mid Jurassic event as envisaged by Curtis and Hyam[36] and Rapela and others[28]. Several mechanisms have been proposed for the rotation associated with the break-up of Gondwana[37,38,39,40]. However, there is neither seismic evidence of the microplate boundaries, nor indications of the extension and compression normally associated with block rotations[41]. No structures were identified nearby the predicted boundaries of the microplate to support the rotation on continental crust.

A recent study by Stanca and others[42] proposed crustal fragmentation and block rotation for the Malvinas Plateau, where the Malvinas Islands were a microcontinent; however, they state that the position of the plateau and the islands before the separation of Gondwana continues to be controversial. This work proposed a Malvinas Islands microplate,

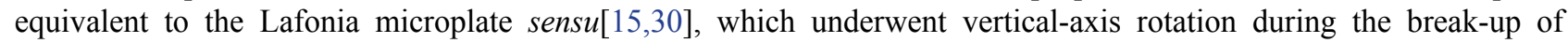
Gondwana. As there is no deformation affecting the sedimentary basins offshore of the islands, rotation would have 
had to occur prior to the older rift that took place in the southern sector of the North Malvinas basin. The oldest synrift deposits are not well dated in that basin, and a doubtful Upper (?) Jurassic age was assumed[42]. However, this WNW to NW-trending rift system, as seen in their Fig. 6, has the same trend as the Early Jurassic rift that crosscut the San Jorge and Cañadón Asfalto basins in Patagonia. The Malvinas rift, as well as its Patagonian equivalent, are linked to the 190-188 Ma old basaltic dike system parallel to the normal faults of the rift, located at the base of the synrift deposits. This WNW to NW-trending rift system crossing from Patagonia to the Malvinas Plateau was related to the opening of the Weddell Sea[1,43]. The rifting process started at about $190 \mathrm{Ma}$ and ended with the first oceanic crust in that sea at about 160-155 Ma according to Ghidella and others[43]. The age of the synrift deposits across Patagonia is well dated and constrained to the Early to Middle Jurassic[44]. Some minor rotation occurred during the synextensional emplacement of the Chon Aike Magmatic Province[45,46] in the Early-Middle Jurassic. The observed rotational extension was recently interpreted by Lovecchio and others as produced by effect of a slab tear between Patagonia and Antarctica[47].

This fact is important because the rotation should have occurred and finished in the Early Jurassic. Furthermore, the paleomagnetic data found by Taylor and Shaw[11] and analyzed by Ramos and others[1] show the expected rotation in one site, while the other two sites have abnormal rotations, difficult to reconcile with a rigid-body vertical-axis rotation such as the one required for the Malvinas Islands microplate.

\section{The mega-décollement controlling the Gondwanide Orogen}

New detailed structural analyses performed north of the Malvinas Islands in the adjacent basin, combined with gravity and seismic data presented by Stanca et al.[42], enhanced the importance of the occurrence of a mega-décollement formed during the Gondwanide Orogeny. This décollement has been recognized underneath the Outeniqua Basin and South Africa[41,48], associated with north-verging thrusts. The décollement described in the Outeniqua Basin and underneath the Cape fold and thrust belt is dipping to the south, and it was reactivated as a detachment level during subsequent extension in Jurassic times. In the Malvinas plateau, this décollement is dipping to the north and reaches the same depth as in the Outeniqua Basin. The opposite polarity of this décollement at both sides of the Agulhas-Malvinas transfer zone is considered as a new evidence supporting the $180^{\circ}$ rotation of the Malvinas Islands microplate[42].

However, if the structural characteristics of the Ventania fold and thrust belt in the province of Buenos Aires are considered, a series of new problems emerges. The seismic sections provided by Pángaro and Ramos[49] (their Figs. 8 and 12), Ramos et al.[19] (their Fig. 5), and Pángaro et al.[19], show withou shadow of a doubt the continuity of the Ventania fold and thrust belt in the adjacent offshore area and its eastern extension in the Cape belt of South Africa (see Paton et al.[20]). In those sections, what the authors considered to be the master shear is the equivalent to the mega-décollement of Stanca et al.[42]. Both structures have the same north-vergence, a similar depth of detachment and equivalent offsets. On top of that, recent studies in the Colorado offshore basin show three periods of extension, the oldest one being controlled by a postorogenic extensional collapse of the thrusts of the Ventania fold belt[17]. These extensionally reactivated Permian to Early Triassic thrusts were intersected by normal faults during Early Jurassic times, in a similar way as that described for the Outeniqua Basin and the Cape fold and thrust belt. It is evident that deformation kinematics north of the Gondwanide magmatic arc and north of the Agulhas-Malvinas transform were comparable.

On the other hand, there is evidence that deformation south of the magmatic arc has an opposite south-vergence, as described in the Sierra Grande area[50] close to the Atlantic margin. A similar conclusion with different approaches was arrived at by von Gosen[51] and López de Luchi and others[52]. Early Paleozoic quartzites are folded and thrusted with a south-southeast vergence (see Figure 3). Further inland, underneath the Mesozoic deposits of the Neuquén Basin, Mosquera et al.[53] recognized the Gondwanide deformation with south-vergent thrusts reactivated during latest TriassicEarly Jurassic extension[54,55,56].

The décollements that controlled the Permian thrusts and the subsequent Early Jurassic normal faults have a dominant south-vergence in the central and southern part of the Neuquén Basin as well as in the outcrops of Sierra Grande area near the Atlantic coast, very similar to the one described in the southern part of the North Malvinas Basin. 


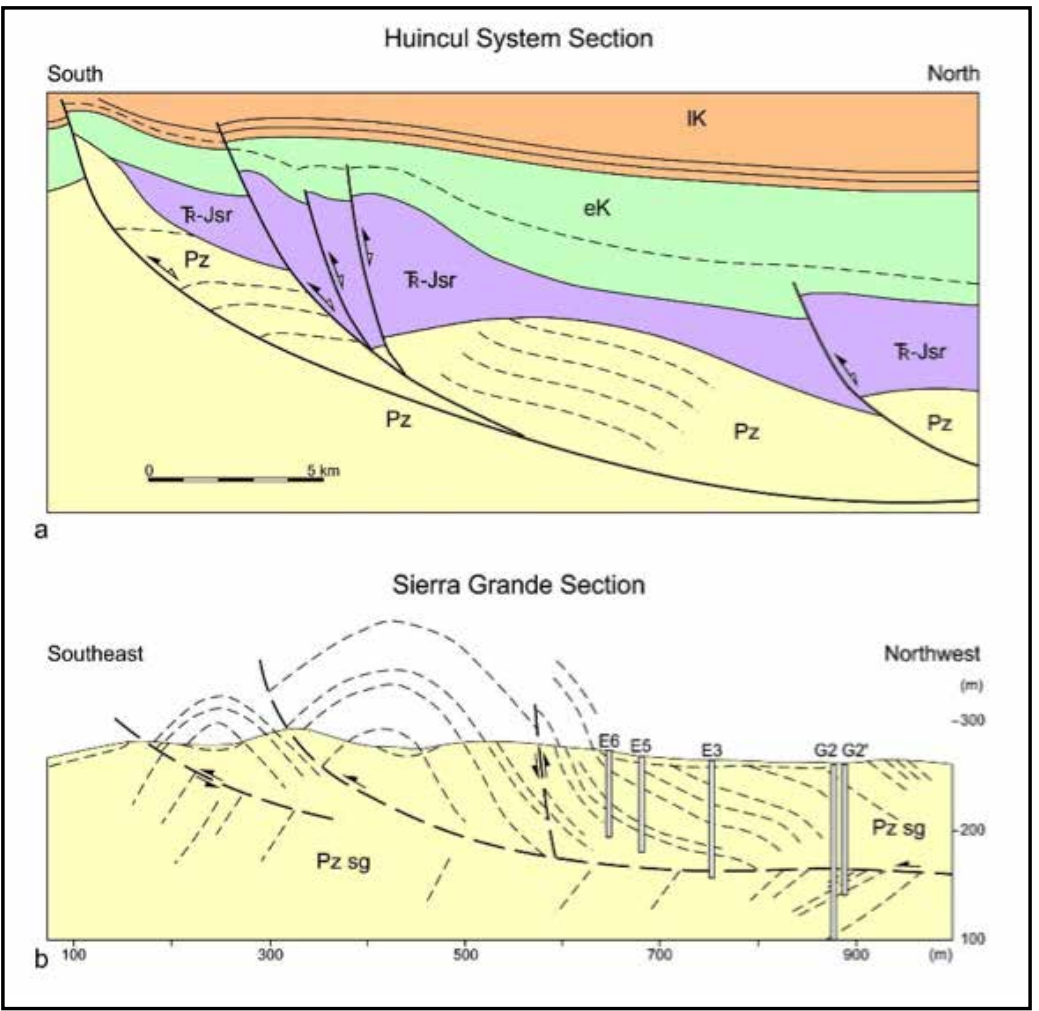

Figure 3. South verging fold and thrust belts developed in northern Patagonia; a) Basement folds with south-vergence in the Huincul System interpreted by Mosquera et al.[53] as Gondwanide thrusts extensionally reactivated during Late Triassic-Early Jurassic, and subsequent contraction in the southern Neuquén Basin. Pz: Paleozoic rocks, TRJsr: synrift deposits of Late Triassic-Early Jurassic age, eK and 1K: Early and Late Cretaceous deposits; b) Silurian-Devonian quartzites with SE-vergence in the Sierra Grande mining district[50] . Pz sg: Sierra Grande Formation. Location of the sections indicated in Fig. 1.

One of the main drawbacks that the rigid model has according to Stanca et al.[42] is the lack of continuation of a south verging fold and thrust belt east and west of the islands. Available seismic information indicates that, at approximately $150 \mathrm{~km}$ west of the islands, the south vergence of the deformation is recognized by the steeper southern flanks of the folds (Figure 4), in comparison with gentler northern flanks[57].

Further to the west, the Mesozoic infill of the Malvinas Basin obliterates the structure of the underlying Paleozoic rocks, as well as the crystalline basement of the Dungeness Arch[1], also known as the Río Chico High[47]. There is some consensus that the Gondwanides has been formed by the collision of Patagonia and adjacent blocks as proposed by Ramos[18] and confirmed by Miller et al.[58] in South Africa.

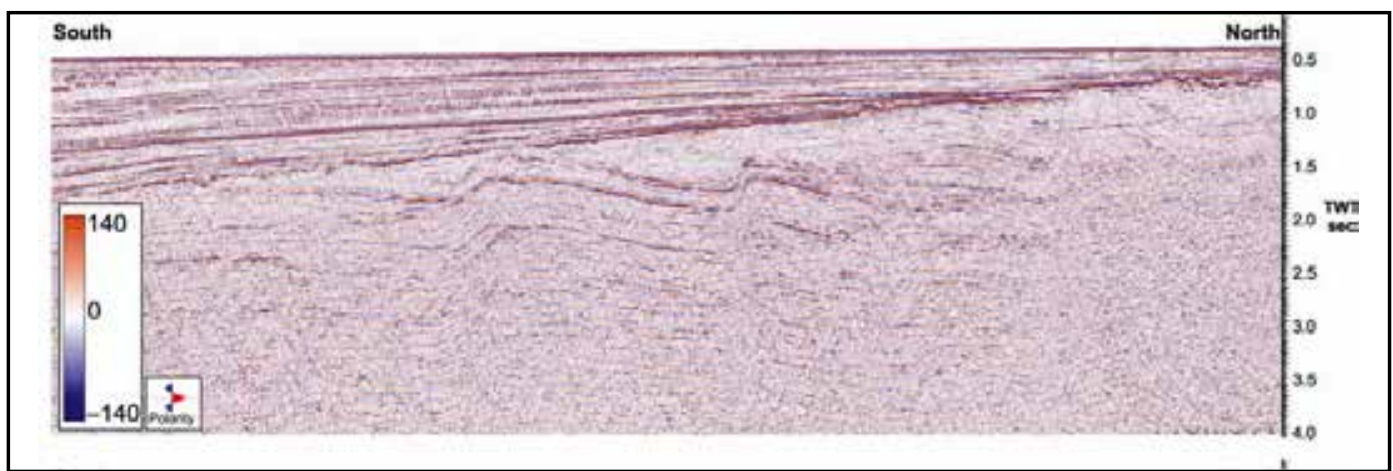

Figure 4. Seismic line southwest of the Malvinas Islands showing, beneath the Jurassic, an angular unconformity of the Gondwanide folds developed in Paleozoic rocks with a well-defined south vergence[57]. See location in Fig. 5. 
West of the Malvinas Basin (Fig. 4), the early Paleozoic clastic platform is interrupted by the Devonian to Carboniferous magmatic arc that was identified by Ramos and Naipauer[59] (and cites therein). The magmatic arc is located along the western side of the Dungeness Arch (or Río Chico High) and continues to the north across the San Jorge Basin with a northwestern trend, to finally reach the northern Patagonian Andes[18]. The quartzitic platform can be recognized from the western off-shore of the Malvinas Islands, to the north in Cabo Blanco, in the basement of the Rawson Basin and in Sierra Grande (Fig. 5). In both extremes the southern vergence of the folds has been identified.

\section{2.- MALVINAS ISLANDS FIXED TO PATAGONIA}

The previous analyses have shown that there is no robust evidence to rotate the Lafonia (Falkland) microplate $120^{\circ}$, either surrounded by continental or oceanic crust. The paleomagnetic data is poor and not conclusive for a vertical-axis rotation; no suture or deformation has been recognized in the western contact with Patagonia, and if it is difficult to rotate the islands, it is almost impossible to rotate the entire Malvinas plateau. The occurrence of two sets of dolerite dykes in the Malvinas Islands, one WNW-trending of Jurassic age, and another one N-trending of Early Cretaceous age, was taken as an evidence of rotation of the islands[23,60]. However, this main stress rotation is seen in the entire Patagonia and in the adjacent offshore basins associated with the Jurassic WNW-trending opening of the Weddell Sea and the subsequent N-trending rifting of the South Atlantic in the Early Cretaceous[1,47].

Most of the similarities between the East Cape Supergroup and the Lafonia Supergroup, the so-called South AfricanMalvinas connection[42], is not taking into consideration the late Paleozoic glacial deposits of central Patagonia, and the exposed Paleozoic quartzites inland in eastern Patagonia (v.g. Sierra Grande and Cabo Blanco), as well as the deposits in the offshore adjacent basins (v.g. Rawson Basin). Besides these arguments[1,59], based on the new data obtained in the Malvinas Plateau, the "fixist alternative" will be analyzed.

\section{New data on the Malvinas Basin}

A recent update of the structural framework for the Malvinas Basin, together with two new U-Pb zircon ages for the synrift series[47] preclude a Lower to Middle Jurassic or younger collision between Patagonia and the Malvinas Islands (see Fig. 6). Recent works assume that the Weddell Sea Rift that separated the Ewing Bank from Gondwana was developed at $\sim 164 \mathrm{Ma}[62]$.

The new $\mathrm{U}-\mathrm{Pb}$ dates are located within the synrift sequence. A volcanic breccia at the base of the sequence has an age of $215 \mathrm{Ma}$ (on top of ROU horizon of Fig. 6), which indicates a Late Triassic age for this level[47]. Triassic deposits are also interpreted in the San Julián offshore rift basin by Figueiredo et al. (1996, see seismic line in Fig. 14), as well as in the El Tranquilo rift onshore Santa Cruz, where they are well known and dated[63,64].

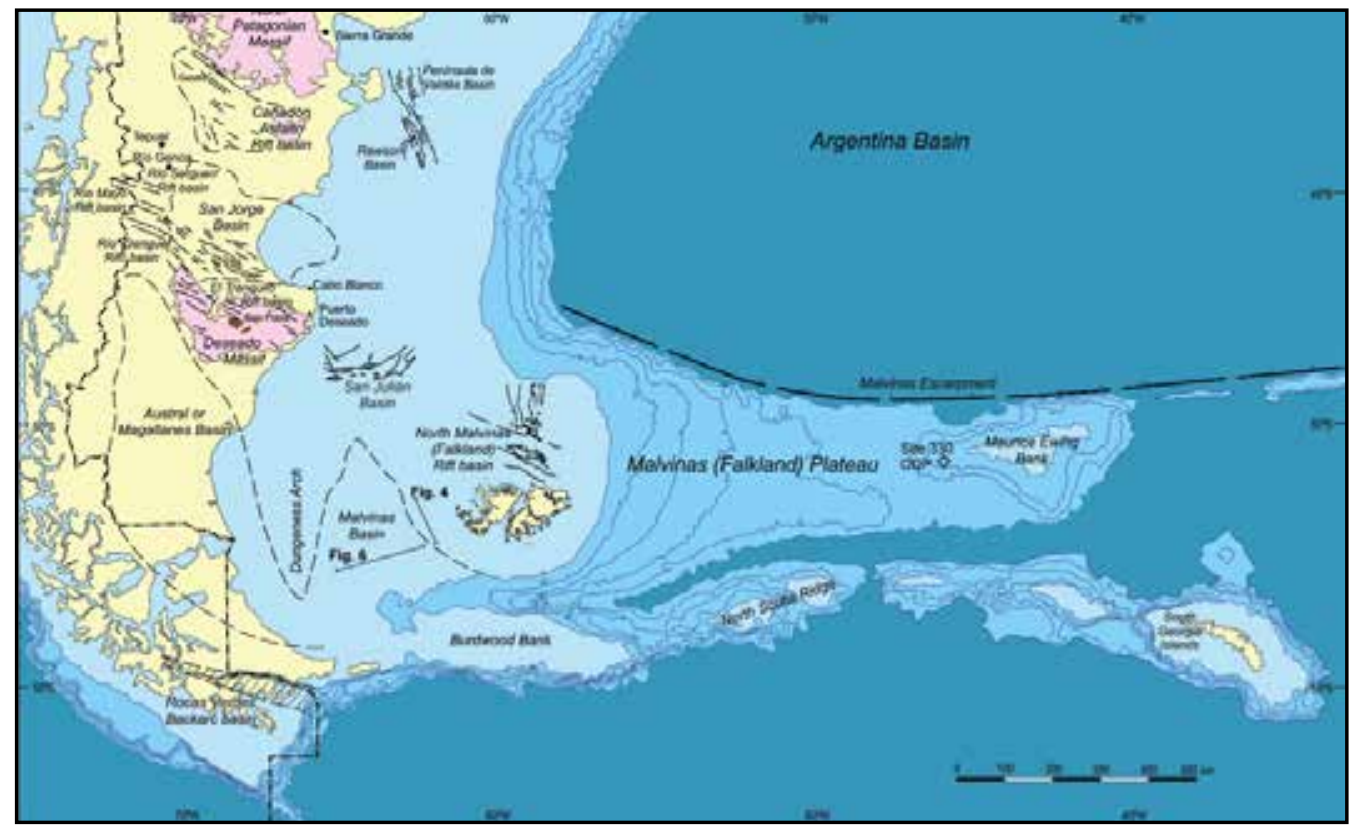

Figure 5. Main characteristics of the Malvinas (Falkland) Plateau and the adjacent Patagonia (modified from Ramos et al.[1] and Chemale et al.[61]. Note the location of the oceanic drill of ODP-330 in the Maurice Ewing Bank, and the location of figures 4 and 6, based on McCarthy et al.[57] and Lovecchio et al.[47]. 


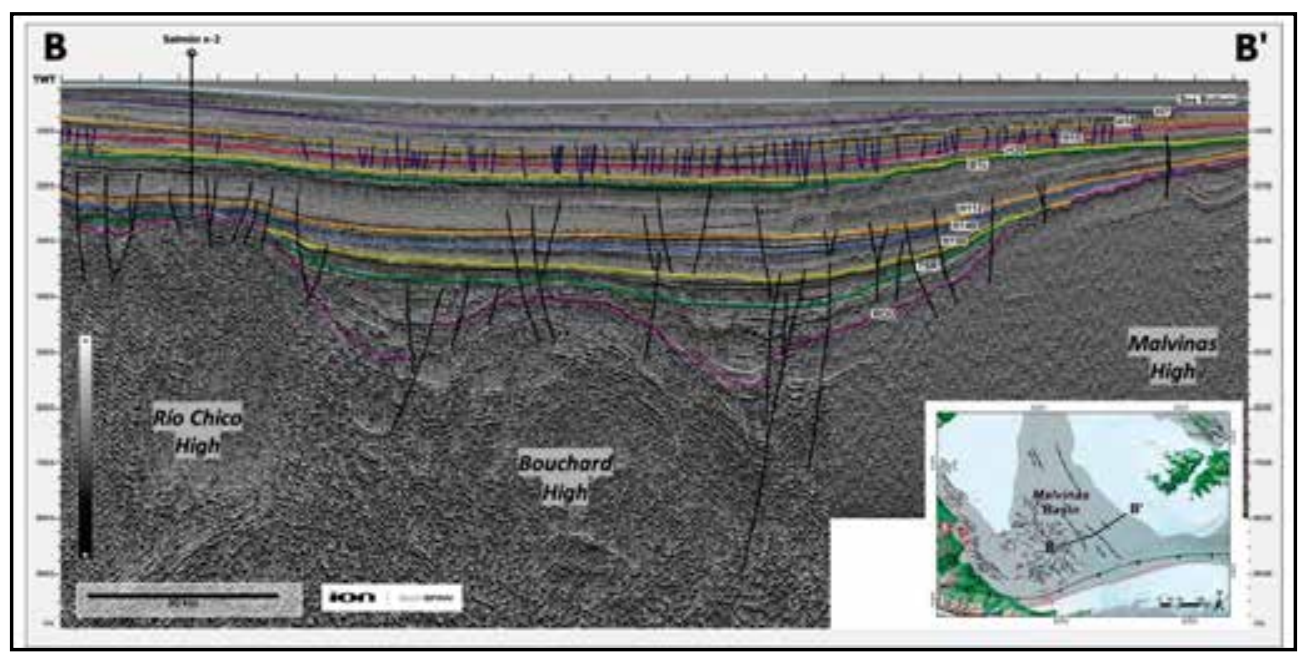

Figure 6. Seismic line across the Central Graben of the Malvinas Basin[47]. The rift sequence is encompassed between the ROU horizon (top pre-rift basement) and the TSR horizon (top synrift).

The second $\mathrm{U}-\mathrm{Pb}$ date yielded $169.6 \pm 2.1 \mathrm{Ma}$ and corresponds to a tuff layer located near the top of the synrift sequence (TSR of Figure 6). This Middle Jurassic age constrains the age of the synrift deposits to Late Triassic- Middle Jurassic times, a similar time span recognized in the San Julián, El Tranquilo, and Cañadón Asfalto rift basins.

The period of time covered by the synrift deposit is the one that has been proposed for the collision of the Malvinas Islands; therefore, a compressive regime is unlikely in this time span.

\section{New data on the Malvinas Plateau}

The recent analyses of Site 330 of ODP presented by Chemale et al.[61] show that the basement of the Maurice Ewing Bank has similar ages to the Gran Malvina (Western) Island basement exposed in Cabo Belgrano (Cape Meredith). These metamorphic rocks have similar Mesoproterozoic U-Pb ages, between 1,200 and 1,030 Ma, and are intruded by pink leucogranites (without any deformation) of 1,006 $\pm 13 \mathrm{Ma}$ in the Maurice Ewing Bank[62]. These ages closely correlate to the metamorphic dated rocks in Cape Meredith, as well as the associated similar pink granites of 1,003 $\pm 16 \mathrm{Ma}$ (Thomas et al., 2000). These basement ages are similar to the detrital zircon ages[1] in the overlying Paleozoic quartzites in both islands, indicating a common basement. The occurrence of similar basement rocks with a common deformation history shows that the current location of the islands with respect to the Maurice Ewing Bank has not changed significantly and should have been even closer than in present times considering the amount of E-W extension recorded in the Malvinas Plateau.

Another important point is that the Jurassic fluvial sandstone over the Maurice Ewing Bank intersected at site 330 carries detrital zircons of Permian age. New geochronological work indicates an important peak at $266 \mathrm{Ma}$ (Chemale et al., in prep.), which is difficult to reconcile with a position just east of South Africa[42,62] (and cites therein). Permian ages are common at these latitudes in the Darwin Cordillera, with a more prominent peak at c. $270 \mathrm{Ma}[65]$; this is well documented for the Patagonian Andes, with a large well-defined 260-300 Ma population likely derived from the Gondwanide belt formed during the Carboniferous-Permian assembly of Patagonia[66], bracketed by Suárez et al.[67] between 255-268 Ma, and even closer, in the South Georgia Island, at its previous position adjacent to eastern Tierra del Fuego Island, with a dominant younger peak at $275 \mathrm{Ma}[68,69]$.

Both sets of data strongly suggest basement continuity between the Malvinas Islands and the Maurice Ewing Bank and their proximity with the Fuegian and Patagonian Andes.

\section{Concluding Remarks}

The previous reviews of Stone[12] and Ramos et al.[1] questioned the reliability of the existing paleomagnetic data, to support a $120^{\circ}$ vertical axis rotation of the entire Malvinas Islands microplate. The fragmentation of the microplate in different blocks as proposed by Stanca et al.[42], on the other hand, is not supported by the existing paleomagnetic data. 
The timing for the rifting of the southern part of the North Malvinas Basin could be partially constrained by the 188$190 \mathrm{Ma}$ old dikes exposed in the Malvinas Islands. The correlation, based on the new data presented by Lovecchio et al.[47], with the adjacent rift of the Malvinas Basin is coherent not only between these two basins, but with the entire extensional trend of southern and central Patagonia (Fig. 5). It is well established that the timing and the direction of this extension was controlled by rifting prior to the opening of the Rocas Verdes Basin and the Weddell Sea, which ended with the first oceanic crust developed at 160-155 Ma[43,70] and references therein).

As discussed by Stanca et al.[42], the rotation of the islands, if it ever occurred, should be prior to the synrift deposits, since these sequences do not show any deformation. If a time span between Late Triassic and Early to Middle Jurassic is accepted for the rifting, rotation should be older than Late Triassic, when most of the Cape belt of South Africa was still under compression.

The several proposed collisions between the Lafonia (or Malvinas) microplate against Patagonia at different times during the Jurassic must be ruled out, since no deformation is observed in the Late Triassic-Early to Middle Jurassic sequences of the Malvinas Basin.

The detrital zircons of Permian age found in the sedimentary cover above the basement of the Maurice Ewing Bank are also indicative of the proximity to the Patagonian or Fuegian Andes, or to the Georgias Islands, in their location prior to the development of the Northern Scotia arc.

Based on these new observations, in addition to the detailed analyses by Stone[12] and Ramos and others[1], it is concluded that the Malvinas Islands and the Maurice Ewing Bank, as an integral part of the Malvinas Plateau, have been attached to Patagonia since Paleozoic times. There is compelling evidence that this land has been part of South America within Western Gondwana, at least since the Permian.

\section{Acknowledgments}

The authors are grateful to the critical review of Dr. Augusto Rapalini and the various suggestions received, which improved the understanding of the work. Additionally, the authors acknowledge numerous colleagues in the Institute for their discussions and exchanges on different aspects. This is contribution R 309 of the Instituto de Estudios Andinos Don Pablo Groeber.

\section{References}

[1] Ramos, V.A.; Cingolani, C.; Chemale Junior, F.; Naipauer, M.; Rapalini, A. The Malvinas (Falkland) Islands revisited: The tectonic evolution of southern Gondwana based on U-Pb and Lu-Hf detrital zircon isotopes in the Paleozoic cover. J. South Am. Earth Sci. 2017, 76: 320-345.

[2] Du Toit, A.L. A geological comparison of South America with South Africa. Publications Carnegie Institute, 1927 , 381: 1-157.

[3] Du Toit, A.L. Our wandering continents. London, Oliver and Boyd, 1937.

[4] Keidel, J. Über das Alter, die Verbreitung und die gegenseitigen Beziehungen der verschiedenen tektonischen strukturen in den argentinischen Gebirgen. XII ${ }^{\circ}$ Session du Congrés Géologique International, Compte Rendu pp. 671-687, Toronto, 1913.

[5] Keidel, J. La geología de las Sierras de la Provincia de Buenos Aires y sus relaciones con las montañas de Sudáfrica y Los Andes. Ministerio de Agricultura de La Nación, Sección Geología, Mineralogía y Minería, Anales, 1916, 11(3), p. 1-78.

[6] Keidel, J. Sobre la distribución de los depósitos glaciares del Pérmico conocidos en la Argentina y su significación para la estratigrafía de la serie del Gondwana y la paleogeografía del Hemisferio Austral. Academia Nacional de Ciencias, Boletín, 1921, 25, p. 239-368, Córdoba.

[7] Adie, R.J. The position of the Falkland Islands in a reconstruction of Gondwanaland. Geol. Mag., 1952, 89: 401-410.

[8] Suero, T. Paleogeografía del Paleozoico superior en la Patagonia (República Argentina). Rev. Asoc. Geol. Arg., 1961,16(1-2), p. 35-42. 
[9] Borrello, A.V. Sobre la geología de las Islas Malvinas, Ediciones Cultura Argentina, Ministerio de Educación y Justicia, 70 pp., Buenos Aires, 1963.

[10] Mitchell, C.; Taylor, G.K.; Cox, K.G.; Shaw, J. Are the Falkland Islands a rotated microplate? Nature, 1986, 319, p. 131-134.

[11] Taylor, G.K.; Shaw, J. The Falkland Islands: new palaeomagnetic data and their origin as a displaced terrane from southern Africa. In Hillhouse, J.W. (ed.) Deep Structure and Past Kinematics of Accreted Terranes, AGU, Geophysical Monographs Series, 50, p. 59-72, Washington, D.C., 1989.

[12] Stone, P. Geological exploration of South Atlantic islands and its contributions to the continental drift debate of the early 20th century. Proceedings of the Geologists'Association, 2015, 126, p. 266-81.

[13] Stone, P. Geology reviewed for the Falkland Islands and their offshore sedimentary basins, South Atlantic Ocean. Earth and Environmental Science Transactions of the Royal Society of Edinburgh, 2016, 106, p. 115-143.

[14] Martin, A.K. Plate tectonics: Microplates in Antartica. Nature, 1986, 319: 100-101.

[15] Ben Avraham, Z.; Hartnady, C.J.H.; Malan, J.A. Early tectonic extension between the Agulhas Bank and the Falkland Plateau due to the rotation of the Lafonia microplate. Earth and Planet. Sc. Lett., 1993, 117, p. 43-58.

[16] Richards, P.C.; Gatliff, R.W.; Quinn, M.F.; Williamson, J.P.; Fannin, N.G.T. The geological evolution of the Falkland Islands continental shelf. In Storey, B.C., King, E.C., Livermore, R.A. (eds.) Weddell Sea Tectonics and Gondwana Breakup. Geol. Soc., Sp. Pub., 1996, 108, p.105-28.

[17] Lovecchio, J.P.; Rohais, S.; Joseph, P.; Bolatti, N.D.; Kress, P.R.; Gerster, R.; Ramos, V.A. Multistage rifting evolution of the Colorado basin (offshore Argentina): Evidence for extensional settings prior to the South Atlantic opening. Terra Nova 2018, 30, p. 359-368.

[18] Ramos, V.A. Patagonia: A Paleozoic continent adrift? J. South Am. Earth Sci., 2008, 26(3), p. 235-251.

[19] Pángaro, F.; Ramos, V.A.; Pazos, P.J. The Hesperides basin: a continental-scale upper Palaeozoic to Triassic basin in southern Gondwana. Basin Research, 2016, 28, p. 685-711.

[20] Paton, D.A.; Mortimer, E.J.; Hodgson, N.; Van Der Spuy, D. The missing piece of the South Atlantic jigsaw: when continental break-up ignores crustal heterogeneity. In Sabato Ceraldi, T., Hodgkinson, R.A., Backe, G. (eds.) Petroleum Geoscience of the West Africa Margin. Geol. Soc. (London) Sp. Pub., 2016, 438, p. 8.

[21] Marshall, J.E.A. The Falkland Islands: A key element in Gondwana paleogeography. Tectonics, 1994, 13, p. 499-514.

[22] Rapela C.W.; Pankhurst, R.J. The granites of northern Patagonia and the Gastre Fault System in relation to the breakup of Gondwana. In Storey, B.C., Alabaster, T., Pankhurst, R.J. (eds.) Magmatism and the Causes of Continental Break-up, Geol. Soc., Sp. Pub., 1992, 68, p. 209-220.

[23] Thomson, K.; Hegarty, K.A.; Marshallsea, S.J.; Green, P.F. Thermal and tectonic evolution of the Falkland Islands: implications for hydrocarbon exploration in the adjacent offshore region. Marine and Petroleum Geology, $2002,19$. p. $95-116$.

[24] Coira, B.L.; Nullo, F.E.; Proserpio, C.; Ramos, V.A. Tectónica de basamento de la región occidental del Macizo Nordpatagónico, provincias de Río Negro y Chubut. Rev. Asoc. Geol. Arg., 1975, 30(4), p. $361-383$.

[25] Franzese, J.; Martino, R. Aspectos cinemáticos y tectónicos de la zona de cizalla de Gastre en la sierra de Calcatapul, provincia de Chubut, Argentina. In $10^{\circ}$ Congreso Latinoamericano de Geología y $6^{\circ}$ Congreso Nacional de Geología Económica, Actas 1998, 2, p. 3.

[26] Von Gosen, W.; Loske, W. Tectonic history of the Calcatapul Formation, Chubut Province, Argentina, and the "Gastre Fault System". Journal of South American Earth Sciences, 2004, 18, p. 73-88.

[27] Klinger, F.L.; Martinez, M.P.; Gimenez, M.E.; Ruiz, F. Profundidades al basamento en el bajo de Gastre, a partir de soluciones de señal analítica, Chubut. Argentina. Latinmag Letters, Special Issue, 2011, 1, p. 1-7, Tandil.

[28] Rapela, C.W.; Pankhurst, R.J.; Fanning, C.M.; Hervé, F. Pacific subduction coeval with the Karoo mantle plume: The Early Jurassic Subcordilleran Belt of northwestern Patagonia. In Vaughan, A.P.M., Leat, P.T., Pankhurst, R.J. (eds.) 
Terrane Accretion Processes at the Pacific Margin of Gondwana. Geol. Soc., Sp. Pub., 2005, 246, p. 217-239.

[29] Martin, A.K. Gondwana breakup via double-saloon-door rifting and seafloor spreading in a backarc basin during subduction rollback. Tectonophysics, 2007, 445, p. 245-72.

[30] Dalziel, I.W.D.; Lawver, L.A.; Norton, I.O.; Gahagan, L.M. The Scotia Arc: Genesis, Evolution, Global Significance. Annual Review of Earth and Planetary Sciences, 2013, 41, p. 767-93.

[31] Andersen, T.; Elburg, M.; Cawthorn-Blazeby, A. U-Pb and Lu-Hf zircon data in young sediments reflect sedimentary recycling in eastern South Africa. J. Geol. Soc., 2016, 173, p. 337-351.

[32] Gong, Z.; Langereis, C.G.; Mullender, T.A.T. The rotation of Iberia during the Aptian and the opening of the Bay of Biscay. Earth and Planet. Sc. Lett., 2008, 273(1-2): 80-93.

[33] Franke, D.; Neben, S.; Schreckenberger, B.; Schulze, A.; Stiller, M.; Krawczyk, C. M. Crustal structure across the Colorado Basin, offshore Argentina. Geophysical Journal International, 2006, 165, p. 850-864.

[34] Torsvik, T.H.; Rousse, S.; Labails, C.; Smethurst, M.A. A new scheme for the opening of the South Atlantic Ocean and the dissection of an Aptian salt basin. Geophys. J. Int., 2009, 177, p. 1315-1333.

[35] Biddle, K.; Snavely III, P.D.; Uliana, M.A. Plateau de las Malvinas. In V.A. Ramos and M.A. Turic (eds.) Geología y Recursos Naturales de la Plataforma Continental Argentina. Asociación Geológica Argentina e Instituto Argentino del Petróleo, p. 225-252, Buenos Aires, 1996.

[36] Curtis, M.L.; Hyam, D.M. Late Palaeozoic to Mesozoic structural evolution of the Falkland Islands: a displaced segment of the Cape Fold Belt. J. Geol. Soc. of London, 1998, 155, p. 115-29.

[37] Storey, B.C.; Curtis, M.L.; Ferris, J.K.; Hunter, M.A.; Livermore, R.A. Reconstruction and break-out model for the Falkland Islands within Gondwana. J. Afr. Earth Sci., 1999, 29, p. 153-63.

[38] Storey, B.C.; Vaughan, A.P.M.; Riley, T.R. The links between large igneous provinces, continental break-up and environmental change: evidence reviewed from Antarctica. Earth and Environmental Science Transactions of the Royal Society of Edinburgh, 2013, 104, p. 17-30.

[39] Dalziel, I.W.D.; Lawver, L.A. The lithospheric setting of the West Antarctic ice sheet. In The West Antarctic Ice Sheet: Behavior and Environment, R.B. Alley, R.A. Bindschadler, Antarct. Res. Ser. 2001, 77, p. 29-44. Washington.

[40] Macdonald, D.; Gómez-Pérez, I.; Franzese, J.; Spalletti, L.; Lawver, L.; Gahagan, L.; Dalziel, I.; Thomas, C.; Trewin, N.; Hole, M.; Paton, D. Mesozoic break-up of SW Gondwana: implications for regional hydrocarbon potential of the southern South Atlantic. Mar. and Petrol. Geol., 2003, 20, p. 287-308.

[41] Tankard, A.; Welsink, H.; Aukes, P.; Newton, R.; Stettler, E. Geodynamic interpretation of the Cape and Karoo basins, South Africa. Phanerozoic Passive Margins, Cratonic Basins and Global Tectonic Maps, 2012, 23, p. 869-945.

[42] Stanca, R.M.; Paton, D.A.: Hodgson, D.M.; McCarthy, D.J.; Mortimer, E.J. A revised position for the rotated Falkland Islands microplate, J. Geol. Soc. (online), 2019, https://jgs.lyellcollection.org/content/jgs/early/2019/01/24/jgs2018163.

[43] Ghidella, M.E.; Yañez, G.; LaBrecque, H.L. Revised tectonic implications for the magnetic anomalies of the Western Weddell Sea. Tectonophysics, 2002, 347(1-3), p. 65-86.

[44] Cúneo, R.; Ramezani, J.: Scasso, R.; Pol, D.; Escapa, I.; Zavattieri, A.M.; Bowring, S.A. High-precision U-Pb geochronology and a new chronostratigraphy for the Cañadón Asfalto Basin, Chubut, central Patagonia: implications for terrestrial faunal and floral evolution in Jurassic. Gondwana Research, 2013, 24, p. 1267-1275.

[45] Gust, D.A.; Biddle, K.T.; Phelps, D.W.; Uliana, M.A. Associated Middle to Late Jurassic Volcanism and Extension in Southern South America. Tectonophysics, 2013, 116, p. 223-253.

[46] Uliana, M.A.; Biddle, K.T.; Phelps, D.W.; Gust, D.A. Significado del vulcanismo y extensión mesojurasicos en el extremo meridional de Sudamérica. Rev. Asoc. Geol. Arg., 1985, 40, p. 231-253.

[47] Lovecchio, J.P.; Naipauer, M.; Lubin Cayo, E.; Rohais, S.; Giunta, D.; Flores, G.; Gerster, R.; Bolatti, N.D.; Joseph, P.; Valencia, V.; Ramos, V.A. Rifting evolution of the Malvinas basin, offshore Argentina: new constrains from zircon 
U-Pb geochronology and seismic characterization. J. South Am. Earth Sci., 2019, 95, p. 102253.

[48] Hälbich, I. W (ed.). The Cape Fold Belt-Agulhas Bank Transect across the Gondwana Suture in southern Africa. American Geophysical Union Special Publication, AGU Press, 202, Washington. 1993.

[49] Pángaro, F.; Ramos, V.A. Paleozoic crustal blocks of onshore and offshore central Argentina: new pieces of the southwestern Gondwana collage and their role in the accretion of Patagonia and the evolution of Mesozoic south Atlantic sedimentary basins. Marine and Petroleum Geology, 2012, 37(1), p. 162-183.

[50] Ramos, V.A.; Cortés, J.M. Estructura e interpretación tectónica. In V. Ramos (ed.) Geología y recursos naturales de la Provincia de Río Negro, $9^{\circ}$ Congreso Geológico Argentino (S.C. Bariloche), Relatorio, p. 317 - 346, Buenos Aires. 1984.

[51] Von Gosen, W. Thrust tectonics in the North Patagonian Massif (Argentina): Implications for a Patagonia plate. Tectonics, 2003, 22, 1, 1005, doi:10.1029/2001TC901039, 2003

[52] López de Luchi, M.G.; Rapalini, A.E.: Tomezzoli, R.N. Magnetic fabric and microstructures of Late Paleozoic granitoids from the North Patagonian Massif: Evidence of a collision between Patagonia and Gondwana? Tectonophysics, 2010, 494, p. $118-137$.

[53] Mosquera, A.; Silvestro J.; Ramos, V.A.; Alarcón, M.; Zubiri, M. La estructura de la dorsal de Huincul. In Leanza, H. et al. (eds.) Geología y Recursos Naturales de la Provincia del Neuquén, $17^{\circ}$ Congreso Geológico Argentino, Relatorio, 2011, p. 385-398, Neuquén.

[54] Silvestro, J.; Zubiri, M. Convergencia oblicua: modelo estructural alternativo para la dorsal neuquina (39 ${ }^{\circ}$ S) Neuquén. Rev. Asoc. Geol. Arg., 2008, 63(1), p. 49-64.

[55] Mosquera, A.; Ramos, V.A. Intraplate deformation in the Neuquén Basin. In S.M. Kay and V.A. Ramos (eds.) Evolution of an Andean margin: A tectonic and magmatic view from the Andes to the Neuquén Basin $\left(35^{\circ}-39^{\circ} \mathrm{S}\right.$ latitude). Geol. Soc. Am., Sp. Paper, 2006, 407, p. 97-124.

[56] Mosquera, A. Mecánica de deformación en la cuenca neuquina, Neuquén. Facultad de Ciencias Exactas y Naturales, Universidad de Buenos Aires, Ph.D. Thesis (online), 2008, 264 pp., Buenos Aires.

[57] McCarthy, D.; Aldiss, D.; Arsenikos, S.; Stone, P.; Richards, P. Comment on "Geophysical evidence for a large impact structure on the Falkland (Malvinas) Plateau". Terra Nova, 2017, 29, p. 411-415.

[58] Miller, W.; de Wit, M.J.; Linol, B.; Armstrong, R. New Structural Data and U/Pb Dates from the Gamtoos Complex and Lowermost Cape Supergroup of the Eastern Cape Fold Belt, in Support of a Southward Paleo-Subduction Polarity. In de Wit, M.J., Linol, B. (eds.) Origin and Evolution of the Cape Mountains and Karoo Basin, Regional Geology Reviews, 2016, p. 35-44.

[59] Ramos, V.A.; Naipauer, M. Patagonia: Where does it come from? Journal of Iberian Geology 2014, 40(2), p. $367-379$.

[60] Thomson, K. When did the Falklands rotate? Mar. Petrol. Geol., 1998, 15, p. 723-736.

[61] Chemale Jr., F.; Ramos, V.A.; Naipauer, M.; Girelli, T.J.; Vargas, M. Age of basement rocks from the Maurice Ewing Bank and the Falkland/Malvinas Plateau. Precambrian Research 2018, 314, p. 28-40.

[62] Hastie, W.W.; Watkeys, M.K.; Smith, A.M. Tectonic significance of the sedimentary and palaeocurrent record at the eastern edge of the Karoo Basin. Jour. Afric. Earth Sci., 2019, 158, p. 103-43.

[63] Homovc J.F.; Constantini, L. Hydrocarbon exploration potential within intraplate shear-related depocenters: Deseado and San Julián basins, southern Argentina. Am. Assoc. Pet. Geol. Bull., 2001, 85(10), p. 1795-1816.

[64] Jenchen, U. 2018. Petrography and geochemistry of the Triassic El Tranquilo Group, Deseado Massif, Patagonia, Argentina: implications for provenance and tectonic setting, J. South Am. Earth Sci. 88, p. 530-550.

[65] Hervé, F.; Fanning, C.M.; Pankhurst, R.J.; Mpodozis, C.; Klepeis, K.; Calderón, M.; Thomson, S.N. Detrital zircon SHRIMP U-Pb age study of the Cordillera Darwin Metamorphic Complex of Tierra del Fuego: sedimentary sources and implications for the evolution of the Pacific margin of Gondwana. J. Geol. Soc., 2010, 167, p. 555-568.

[66] Barbeu, D.L.; Olivero, E.B.; Swanson-Hysell, N.L.; Zahid, K.M.; Murray, K.E.; Gehrels, G.E. Detrital-zircon 
geochronology of the eastern Magallanes foreland basin: Implications for Eocene kinematics of the northern Scotia Arc and Drake Passage. Earth and Planet. Sc. Lett., 2009, 284, p. 489-503.

[67] Suárez, R.; González, PG.; Ghiglione, M.C. A review on the tectonic evolution of the Paleozoic-Triassic basins from Patagonia: Record of protracted westward migration of the pre-Jurassic subduction zone. J. South Am. Earth Sci., 2019, 95, https://doi.org/10.1016/j.jsames.2019.102256

[68] Carter, A.; Curtis, M.; Schwanethal, J. Cenozoic tectonic history of the South Georgia microcontinent and potential as a barrier to Pacific-Atlantic through flow. Geology, 2014, 42(4), p. 299-302.

[69] Riley, T.A.; Carter, A.; Leat, P.T.; Burton-Johnson, A.; Bastias, J.; Spikings, R.A.; Tate, A.J.; Bristow, C.S. Geochronology and geochemistry of the northern Scotia Sea: A revised interpretation of the North and West Scotia ridge junction. Earth and Planet. Sc. Lett., 2019, 518, p. 136-147.

[70] Ghiglione, M. Orogenic Growth of the Fuegian Andes $\left(52-56^{\circ}\right)$ and Their Relation to Tectonics of the Scotia Arc. In Folguera et al. (eds.), Growth of the Southern Andes, Springer Earth System Sciences, 2016, p. 241-267.

\section{Bios}

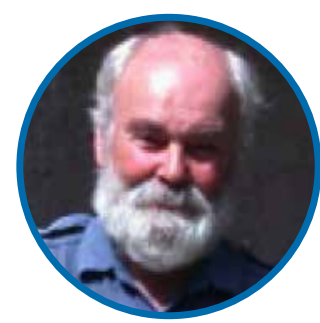

\section{Victor A. Ramos}

Professor at the University of Buenos Aires and Researcher Emeritus of CONICET, Victor has studied the tectonic evolution of the Andes for more than 50 years, making numerous contributions to knowledge on this topic. He has also worked on the geological evolution of the Argentine continental shelf and the Malvinas plateau. He has directed more than 30 doctoral theses on these topics and is currently a researcher at Instituto de Estudios Andino don Pablo Groeber. Corresponding author. Email: victoralbertoramos@gmail.com.

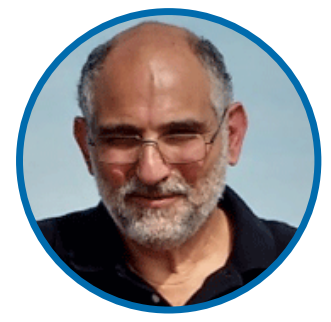

\section{Farid Chemale}

Farid Chemale Junior is an expert on tectonics working in South America, southern Africa and Antarctic. He earned a B.A. of Geology in 1978 from UNISINOS and a M.S of Geosciences in 1982 from UFGRS. He holds a degree in Nature Sciences from TU Clausthal, Ph.D. (1987). He is currently a Professor of Geology Graduate Program at UNISINOS and has previously served as member of the staff at the University of Brasilia, Ouro Preto and Rio Grande do Sul. He has written 196 research papers focused on tectonics, stratigraphy, geochemistry and isotope studies.

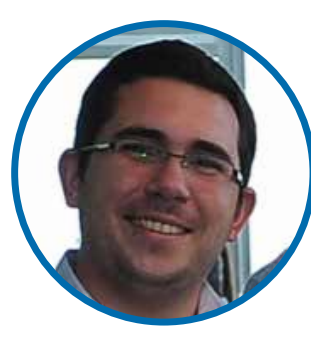

\section{Jaun Pablo Lovecchio}

Juan Pablo Lovecchio works as Senior Exploration Geologist at YPF. He obtained a Geology degree from the National University of Córdoba in 2009, a M.Sc. in Petroleum Exploration from IFP-School (France) in 2011, and a PhD from the University of Buenos Aires and Sorbonne University (France) in 2018. He has more than ten years of experience working in frontier exploration across South America and Africa. For the last 5 years, he has been involved in the exploration of the main Argentinean offshore basins.

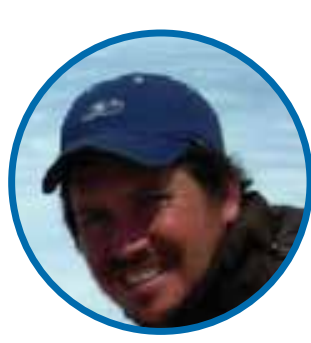

\section{Maximiliano Naipauer}

Maximiliano Naipauer is Doctor in Natural Sciences (2007) from University of La Plata. His main research topic is provenance analysis of sedimentary and metasedimentary rocks based on $\mathrm{U}-\mathrm{Pb}$ ages in detrital zircons of the Neuquén Basin, Sierras Pampeanas and from Precordillera. He is Full Professor of Regional Geology at the University of La Plata, and head and researcher in the Institute of Geochronology and Isotopic Geology of the University of Buenos Aires - CONICET. He has a vast experience in Geochronology and has worked in different laboratories in Brazil and USA. 